\title{
Pengaruh Media Pembelajaran Terhadap Motivasi Belajar Bahasa Arab Siswa Madrasah Tsanawiyah
}

\author{
Wakhidati Nurrohmah Putri \\ IAIN Salatiga \\ wakhidputri@gmail.com \\ DOI: http://dx.doi.org/10.18326/lisania.v1i1.1-16
}

\begin{abstract}
The efforts to increase learning motivation can be done by using instructional media. This study aims to find out the use of media and the effect of the use of instructional media towards motivation to learn Arabic. This is a descriptive quantitative research. The population in this study are 94 students of immersion class at State Islamic Junior High School (MTs N) Plupuh Sragen. All students become the sample in this study. The data is processed by using descriptive statistics and correlation test of Product Moment. Based on the hypothesis test, the magnitude of the correlation coefficient ( $r$ ) is 0.4723 greater than 0.207 with significance level of 5\%. It can be concluded that Ha that there is "the effect of the use of instructional media to learn Arabic student motivation" is accepted. The results inform that there is a significant effect of media learning towards student motivation, especially in learning Arabic.
\end{abstract}

Keywords: learning media, learning motivation, Arabic, Islamic Junior High School

\begin{abstract}
Abstrak
Upaya untuk meningkatkan motivasi atau minat belajar siswa dapat dilakukan dengan menggunakan media pembelajaran. Penelitian ini bertujuan untuk mengetahui tentang penggunaan media pembelajaran dan pengaruh penggunaan media pembelajaran bahasa Arab terhadap motivasi belajar bahasa Arab. Penelitian ini merupakan penelitian kuantitatif deskriptif. Populasi dalam penelitian ini adalah semua siswa kelas uanggulan MTs N Plupuh Sragen yang berjumlah 94 siswa. Seluruh siswa tersebut dipilih menjadi sampel dalam penelitian ini. Data diolah menggunakan statistik deskriptif dan uji korelasi Product Moment. Berdasarkan uji hipotesis diperoleh besarnya koefisien korelasi (r) adalah 0,4723 lebih besar dari 0,207 dengan taraf signifikan 5\%. Dengan demikian dapat disimpulkan bahwa Ha diterima, yaitu terdapat "pengaruh penggunaan media pembelajaran terhadap motivasi belajar bahasa Arab siswa". Hasil penelitian ini menginformasikan terdapat pengaruh yang signifikan antara media pembelajaran terhadap motivasi belajar siswa, khusunya dalam belajar bahasa Arab.
\end{abstract}

Kata kunci: media pembelajaran, motivasi belajar, bahasa Arab, siswa madrasah tsanawiyah 


\section{Pendahuluan}

Perkembangan zaman yang dipengaruhi oleh ilmu pengetahuan dan teknologi yang maju, dapat berpengaruh juga dalam proses pembelajaran. Pembelajaran pada masa kini seharusnya dapat meningkatkan kemampuan seseorang untuk menyesuaikan diri dengan perkembangan teknologi. Hal ini disebabkan karena seseorang tidak dapat lepas dari pembelajaran dan proses pembelajaran. Pembelajaran sendiri merupakan proses belajar mengajar untuk mendapatkan tujuan tertentu. Suatu kegiatan pembelajaran akan dikatakan berhasil apabila terbentuk interaksi dan komunikasi timbal balik yang aktif antara guru dan siswa selama proses belajar.

Belajar adalah proses yang kompleks yang terjadi pada diri setiap orang sepanjang hidupnya. Poses belajar itu terjadi karena adanya interaksi antara seseorang dengan lingkungannya. Oleh karena itu belajar dapat terjadi kapan saja dan di mana saja. Salah satu pertanda bahwa seseorang belajar adalah adanya perubahan tingkah laku pada diri orang itu yang mungkin disebabkan oleh terjadinya perubahan tingkah laku pada diri orang itu yang mungkin disebabkan oleh terjadi perubahan pada tingkat pengetahuan, ketrampilan atau sikapnya. Proses belajar mengajar pada dasarnya adalah penyampaian pesan dari sumber pesan kepada penerima pesan dengan cara atau media tertentu (Arief, 2002: 11). Penggunaan media pembelajaran belum sepenuhnya diterapkan pada setiap sekolah. Salah satu penyebabnya karena keterbatasan fasilitas yang disediakan oleh sekolah.

Bahasa Arab adalah salah satu mata pelajaran yang menempati posisi penting dalam dunia pendidikan. Khususnya lembaga pendidikan Islam baik negeri maupun swasta pada jenjang dan program tertentu, Bahasa Arab merupakan suatu keharusan untuk diajarkan kepada siswa mereka. Ruang lingkup pembelajaran bahasa Arab meliputi: unsur kebahasaan, keterampilan berbahasa, dan aspek budaya. Dimana unsur kebahasaan sendiri terdiri atas tata bahasa (qawâ'idu al-lughah), kosa kata (mufradât), pelafalan dan ejaan (ashwât 'arabiyyah). Sedang ketrampilan berbahasa meliputi keterampilan menyimak (mahâratu al-istimâ'), keterampilan berbicara (mahâratu alkalâm), keterampilan membaca (mahâratu al-qirâ'ah) dan keterampilan menulis (mahâratu al-kitâbah). Aspek budaya merupakan makna yang terkandung dalam teks lisan dan tulisan. 
Proses pengajaran bahasa dikenal ada empat keterampilan atau kemahiran berbahasa, seperti yang telah disebutkan di atas. Keempat keterampilan berbahasa ini harus diajarkan kepada siswa dengan cara yang bermacam-macam, bervariasi agar siswa tidak jenuh dan monoton terhadap apa yang mereka terima dari pendidiknya. Syarat minimal yang harus dipenuhi oleh guru dalam keterampilan berbahasa ialah penguasaan materi tentang keterampilan berbahasa dan dapat menyampikan materi kepada siswanya.

Guru adalah salah satu komponen penting yang menentukan keberhasilan siswa dalam kegiatan belajar mengajar. Guru sebagai fasilitator dalam kegiatan pembelajaran memegang peranan penting dalam meningkatkan kualitas dan prestasi siswa, terutama dalam belajar bahasa Arab. Guru harus benar-benar memperhatikan, memikirkan dan sekaligus merencanakan proses pembelajaran yang menarik bagi siswa, agar siswa semangat dalam belajar dan mau terlibat aktif dalam proses pembelajaran, sehingga pembelajaran tersaebut menjadi efektif.

Setiap guru mempunyai metode pembelajaran yang berbeda dan bervariasai. Adanya berbagai macam metode dalam pembelajaran dilakukan karena agar siswa yang menerima materi tidak jenuh dengan satu metode. Selain itu, setiap guru diharapkan untuk memiliki ketrampilan dalam memilih alat atau media yang berbeda sesuai kebutuhan proses belajar mengajar. Ketrampilan guru dalam menggunakan media pembelajaran akan memberikan semangat belajar siswanya dalam menerima materi. Dalam hal ini, untuk mempelajari bahasa Arab diperlukan dorongan yang kuat dari dalam diri siswa sendiri maupun dorongan dari luar diri siswa.

Motivasi seseorang dalam belajar bahasa arab, secara umum dapat dibedakan menjadi dua, yaitu: adanya dorongan yang kuat untuk mengambil manfaat secara materi, dan adanya dorongan yang kuat untuk berpenampilan dan bergaya (Abdul hamid, 2008: 160). Motivasi juga dapat muncul ketika seorang siswa mengetahui bahwa bahasa arab merupakan salah satu bahasa internasional. Motivasi sendiri adalah dorongan dasar yang menggerakkan seseorang melakukan sesuatu (Hamzah, 2008: 1). Motivasi belajar merupakan hal yang penting dan perlu diketahui oleh setiap guru dalam perannya untuk menumbuhkan rasa senang dan semangat dalam belajar bagi siswa. Motivasi ini berkaitan dengan keterlibatan siswa dalam ajtivitas di kelas, seperti dorongan untuk melakukan sesuatu berdasarkan tujuan tertentu. 
Berdasarkan observasi proses pembelajaran bahasa Arab yang dilakukan di MTsN Plupuh Sragen, khususnya kelas unggulan VII, diketahui pada saat pembelajaran berlangsung siswa kurang memperhatikan penjelasan guru, hal tersebut terlihat ketika guru memberi pertanyaan, sebagian besar dari mereka tidak menjawab. Pada saat guru menjelaskan materi pembelajaran di depan kelas, sebagian besar siswa tidak memiliki motivasi untuk mengikuti pelajaran, dan sibuk dengan kegiatan masing-masing. Dengan demikian membangkitkan motivasi siswa dalam belajar bahasa Arab menjadi urgen untuk dilakukan oleh guru dalam proses pembelajaran. Salah satu cara untuk membangkitkan motivasi belajar yaitu dengan menggunakan media pembelajaran yang menarik. Berdasarkan latar belakang di atas, penelitian ini dilakukan untuk mengetahui tingkat penggunaan media pembelajaran dan pengaruhnya terhadap motivasi belajar siswa dalam belajar bahasa Arab di MTsN Plupuh.

\section{Metodologi Penelitian}

Jenis Penelitian dalam penelitian ini adalah penelitian kuantitatif deskriptif. Populasi dalam penelitian ini adalah semua siswa kelas unggulan MTs N Plupuh Sragen yang berjumlah 94 siswa. Menurut Suharsimi Arikunto (2006: 131) bahwa Sampel adalah sebagian batau wakil populasi yang diteliti. Jika kurang dari 100, lebih baik semua populasi digunakan. Tetapi jika jumlah populasi lebih dari 100, maka diambil 1015 atau 20-25\% atau lebih. Berdasarkan pertimbangan tersbut, maka seluruh populasi dalam penelitian ini digunakan sebagai subyek penelitian.

Pengumpulan data dalam penelitian ini dilakukan dengan dokumentasi yang digunakan untuk memperoleh data mengenai nilai mata pelajaran Bahasa Arab Siswa dan angket yang digunkan untuk memperoleh data mengenai penggunaan media dan motivasi belajar siswa. Instrumen penelitian ini menggunakan angket dengan model check list dengan skala likert, dimana responden tinggal membubuhkan tanda rumput (v) pada kolom jawaban yang terdiri dari 4 skala yaitu: 1) Sangat Setuju (SS) dengan skor 4, 2) Setuju (S) dengan skor 3, 3) Tidak Setuju (TS) dengan skor 2, dan 4) Sangat Tidak Setuju (STS) dengan skor 1. Yang sesuai dengan kondisi yang dialami dan dihadapi oleh responden.

Langkah-langkah yang ditempuh dalam mengembangkan instrumen yaitu: 1) menyusun indikator variabel penelitian, 2) menyusun kisi-kisi instrumen, 3) melakukan ujicobe instrumen, dan 4) melakukan pengujian validitas dan reliabilitas. Teknik 
statistik yang digunakan dalam penelitian ini adalah statistik deskriptif dan statistik inferensial. Instrumen yang digunakan untuk mengetahui bagaimana penggunaan media pembelajaran untuk penelitian ini adalah dengan menggunakan angket, dengan kisi pernyataan angket adalah: 1) penggunaan media visual, 2) penggunaan media audio, dan 3) penggunaan media audio visual. Instrumen untuk mengukur motivasi belajar, menggunakan kisi pernyataan: 1) hasrat dan keinginan belajar; 2) dorongan dan kebutuhan dalam belajar; 3) harapan dan cita-cita masa depan; 4) penghargaan dalam belajar; 5) kegiatan yang menarik dalam belajar; dan 6) lingkungan belajar yang kondusif.

\section{Media pembelajaran}

Media dalam perspektif pendidikan merupakan instrumen yang sangat strategis dalam ikut menentukan proses belajar mengajar. Sebab keberadaanya secara langsung dapat memberikan dinamika tersendiri terhadap siswa. Media berasal dari bahasa latin yaitu "medium" yang berarti perantara, sedangkan dalam bahasa Arab media berasal dari kata wasaaila artinya pengantar pesan dari pengirim kepada penerima pesan (Azhar Arsyad, 2006: 3). Menurut Imam Makruf, 2009: 124 Media adalah hal-hal yang dapat membantu menyampaikan pesan dari pemberi pesan (guru) kepada penerima pesan (siswa). Media berfungsi sebagai alat penyampaian pesan dari pemberi kepada penerima pesan. Media biasanya berupa benda fisik yang didesain secara khusus maupun digunakan apa adanya dengan tujuan menyampaikan pesan dalam pembelajaran.

Menurut Abdul Hamid (2008: 170) Media pembelajaran merupakan wahana penyalur atau wadah pesan pembelajaran. Sedangkan menurut Muhammad Yunus dan Muhammad Qosim (1996:41) media pembelajaran adalah segala sesuatu yang digunakan guru untuk memberikan informasi dan menyajikan materi agar mudah untuk dipahami dan dimengerti oleh siswa. Berdasarkan beberapa pengertian diatas, media pembelajaran adalah alat penyampaian pesan dari pemberi pesan dalam hal ini guru kepada penerima pesan (siswa) dalam proses belajar mengajar, agar mudah dipahami, dimengerti dan ditangkap oleh siswa.

\section{Macam-Macam Media Pembelajaran}

Macam-macam media pembelajaran jika ditinjau dari segi penggunaan media dikaitkan dengan indera yang digunakan manusia untuk memperoleh pengetahuan, 
maka media diklasifikasikan menjadi tiga macam yaitu: media pandang (visual/bashariyah), media dengar (audio/sam'iyah), dan media pandang dengar (sam'iyabashariyah/ audiovisual) (Abdul Hamid, 2005: 175). Menurut Abdul Salim dalam Azhar Arsyad (2004:76) ada beberapa bentuk media pengajaran, yaitu: a) Benda aslinya; b) contoh riil dalam bentuk patung/permainan; c) gambar-gambar; d) Peta; e) chart; f) papan tulis; g) kartu-kartu; dan h) kaset dan tape recorder.

Menurut Surakhmand (1994:144), alat-alat pembelajaran (ditinjau segi tingkatan pengalaman murid) dibagi menjadi tiga kelompok, yaitu (a) alat-alat yang berupa benda riil (kotak, kapur, papan tulis); (b) alat-alat benda pengganti (bentuk tiruan seperti gambar); (c). bahasa lisan dan tulisan. Mustofa (tt:20) mengelompokkan media pembelajaran bahasa menjadi tiga: Audio visual aids (as Samiyah al Bashariyah), kelompok rangkaian aktifitas (majmuatul amal), dan praktikum (majmuatul mulakhadhah). Muh Ahmad Salim dalam Imam Makruf mengemukakan media pembelajaran Bahasa Arab yang dapat digunakan adalah 1) Laboratorium Bahasa dengan berbagai macamnya; 2) Media Audio, seperti radio; 3) media visual (media cetakan, media proyeksi dan contoh barang); 4) media audio visual, seperti film bersuara, video, dan televisi; dan 5) media pembelajaran berprogram.

\section{Fungsi, Tujuan dan Manfaat Media Pembelajaran}

Dalam proses belajar-mengajar, media mempunyai fungsi penting. Secara umum, media berfungsi sebagai penyampai pesan. Selain fungsi tersebut Hamalik (1994) mengemukakan bahwa penggunaan media dalam proses belajar mengajar dapat membangkitkan rasa ingin tahu dan minat, membangkitkan motivasi dan rangsangan dalam proses belajar-mengajar, serta dapat mempengaruhi psikologi siswa. Penggunaan media juga dapat membantu siswa dalam meningkatkan pemahaman, menyajikan materi/data dengan menarik, memudahkan menafsirkan data, dan memadatkan informasi. Adapun fungsi utama media pembelajaran adalah sebagai alat bantu mengajar yang turut mempengaruhi iklim, kondisi, dan mengajar yang turut mempengaruhi iklim, kondisi, dan lingkungan belajar yang ditata dan diciptakan oleh guru.

Tujuan utama adanya media pembelajaran adalah agar pesan atau informasi yang akan disampaikan pemberi informasi (guru) dapat diserap secara maksimal oleh penerima pesan (siswa). Dengan adanya media pembelajaran, informasi akan lebih 
cepat dan mudah diproses oleh para siswa tanpa harus melalui proses yang panjang yang akan menjadikannya jenuh atau bosan.

Menurut Nana Sudjana manfaat media dalam proses belajar siswa adalah pengajaran akan lebih menarik perhatian siswa, bahan pengajaran lebih jelas maknanya sehingga mudah dipahami, metode pengajaran juga akan lebih bervariasi, dan juga siswa lebih banyak melakukan kegiatan belajar, karena tidak semata-mata hanya mendengarkan uraian guru, tetapi juga melakukan aktivitas lain seperti mengamati, melakukan, mendemonstrasikan dan lain-lain.

Manfaat praktis dari penggunaan media pembelajaran menurut Arsyad (2006: 25) adalah: a) memperjelas penyajian pesan dan informasi; b) meningkatkan dan mengarahkan perhatian; c) dapat mengatasi keterbatasan indera, ruang dan waktu; 4) memberikan kesamaan pengalaman kepada siswa tentang peristiwa-peristiwa di lingkungan mereka.

Berkaitan dengan penggunaan media pada waktu pembelajaran setidaknya digunakan guru pada situasi: a) perhatian siswa sudah berkurang akibat kebosanan mendengarkan uraian; b) bahan materi yang dijelaskan guru kurang dipahami siswa; dan c) terbatasnya sumber belajar siswa. Dengan demikian, media hanya sebagai alat dan sumber belajar sehingga tidak bisa menggantikan peran guru sepenuhnya. Artinya media tanpa guru adalah hal yang mustahil untuk meningkat mutu dan kualitas pembelajaran. Keberadaan media dalam pembelajaran sangat membantu dan diperlukan. Pada dasarnya motivasi dapat membantu dalam memahami dan menjelaskan perilaku individu, termasuk individu yang sedang belajar. Peranan motivasi dalam belajar antara lain dalam menentukan hal-hal yang dapat menjadikan penguat belajar, yaitu dengan guru mengaitkan isi pelajaran dengan perangkat apapun yang berada paling dekat dengan siswa, memperjelas tujuan belajar yang hendak dicapai, menentukan kendali terhadap rangsangan belajar, dan menentukan ketekunan belajar.

Dengan poin-poin di atas maka sebenarnya penggunaan media sangatlah membantu guru dalam menyampaikan materi pembelajaran, karena dengan menggunakan media pembelajaran, guru tidak harus mengulang-ulang penjelasan mengenai isi pelajaran. Selain memperingan guru, juga mempermudah siswa dalam memahami dan mengingat materi yang diajarkan. 


\section{Pemilihan Media Pembelajaran}

Dalam memilih media pembelajaran perlu memperhatikan hal-hal berikut: 1) ketepatan dengan tujuan pembelajaran; 2) keterkaitan dengan isi bahan pelajaran; 3) kemudahan dalam memperoleh media; 4) keterampilan guru dalam menggunakan media; 5) tersedianya waktu untuk menggunakan media; 6) sesuai dengan taraf berfikir siswa. Dengan kriteria tersebut, guru dapat lebih mudah menentukan media mana yang tepat untuk membantu mempermudah tugas-tugasnya sebagai guru. Namun, kehadiran media dalam proses pembelajaran jangan dipaksakan sehingga hal tersebut akan mempersulit guru, tapi harus sebaliknya yakni mempermudah guru dalam menjelaskan bahan materi pelajaran.

Muh. Ahmad Salim (Imam Makruf, 2009: 151) juga memberikan saran tentang bagaimana memilih media yang sesuai dengan materi yang diajarkan, yaitu: 1) Guru membatasi tujuan pembelajaran, kemudian pilih media yang paling banyak dapat mewujudkan tujuan tersebut. 2) pilih media yang mudah didapat dan mudah cara penggunaannya. 3) Pilih media yang memberikan motivasi dan daya tarik bagi siswa. 4) pilih media yang baik, yang dapat memberikan informasi, 5) pilih media yang sesuai dengan tingkatan siswa yang kiranya tidak menimbulkan bahaya. Dan 6) sebelum digunakan, pastikan dicoba terlebih dahulu dan persiapkan tempat untuk menggunakannya.

Berkaitan dengan penggunaan media pada waktu pembelajaran setidaknya digunakan guru pada situasi: a) perhatian siswa sudah berkurang akibat kebosanan mendengarkan uraian; b) bahan materi yang dijelaskan guru kurang dipahami siswa; dan c) terbatasnya sumber belajar siswa. Dengan demikian, media hanya sebagai alat dan sumber belajar sehingga tidak bisa menggantikan peran guru sepenuhnya. Artinya media tanpa guru adalah hal yang mustahil untuk meningkat mutu dan kualitas pembelajaran. Keberadaan media dalam pembelajaran sangat membantu dan diperlukan. Beberapa pertimbangan yang mendasari pentingnya sebuah media secara garis besar adalah untuk lebih mendekatkan pembelajaran kepada bentuk konkrit. Salah satu gambaran yang banyak dijadikan acuan dalam penggunaan media dalam suatu proses pembelajaran adalah dalam Dale's Cone of Experience (Kerucut Pengalaman Dale), seperti yang ditujukan pada gambar di bawah. Berdasarkan kerucut pengalaman tersebut dapat dijelaskan bahwa semakin konkrit dan komplek pengalaman belajar 
siswa, akan semakin mudah memahami, dan semakin banyak materi yang dapat dipelajari (Imam Makruf, 2009: 127).

Gambar 1. Kerucut Pengalaman Dale

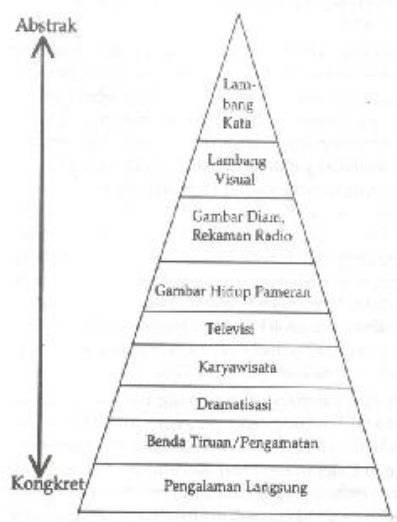

Ada beberapa hal yang perlu diperhatikan guru dalam menggunakan media pembelajaran untuk mempertinggi mutu dan kualiatas pembelajaran. Pertama, guru perlu memiliki pemahaman media pembeljaran antara lain, jenis dan manfaat media pembelajaran, kriteria dalam memilih dan menggunakan media pembelajaran, menggunakan media pembelajaran sebagai alat bantu mengajar. Kedua, guru harus terampil membuat media pembelajaran sederhana untuk keperluan pembelajaran. Ketiga, guru harus mempunyai pengetahuan dan keterampilan dalam menilai keefektifan penggunaan media dalam kegiatan pembelajaran.

\section{Konsep Motivasi}

Motivasi merupakan daya penggerak dalam diri seseorang untuk melakukan kegiatan, demi mencapai tujuan tertentu, motivasi juga merupakan dorongan yang terdapat dalam diri seseorang untuk berusaha mengadakan perubahan tingkah laku yang lebih baik dalam memenuhi kebutuhannya (Hamzah, 2008:3). Menurut McDonald (Oemar Hamalik, 2002:173), "Motivation is a energy shange within the person characterized by affective arousal and anticipatory goal reactions". Motivasi adalah suatu perubahan energi di dalam pribadi seseorang yang ditandai dengan timbulnya afektif dan reaksi untuk mengantisipasi tercapainya tujuan.

Motivasi menurut Ngalim Purwanto (2004:73) adalah suatu usaha yang disadari untuk menggerakkan, mengarahkan dan menjaga tingkah laku seseorang agar dirinya 
terdorong untuk bertindak melakukan sesuatu sehingga mencapai hasil atau tujuan tertentu. Menurut Nana Syaodih Sukmadinata (2003: 61) motivasi didefinisikan sebagai kekuatan yang menunjuk suatu dalam diri individu dan mendorong atau menggerakkan individu tersebut melakukan kegiatan untuk mencapai sesuatu tujuan. Sementara itu Winkel (1991: 92) menyatakan bahwa motivasi ialah keseluruhan daya penggerak psikis di dalam diri siswa yang menimbulkan kegiatan belajar, menjamin kelangsungan belajar dan memberikan arah kegiatan belajar itu demi mencapai suatu tujuan.

Macam atau jenis dari motivasi ada dua, yaitu a) motivasi Intrinsik, yaitu motivasi yang tumbuh dari diri sendiri tanpa dirangsang, dipicu atau dipengaruhi dari pihak luar; motivasi dari dalam dapat berupa keinginan untuk berhasil, keinginan untuk maju dankeinginan untuk memperoleh pengetahuan serta keinginan untuk mengembangkan pengetahuan yang dimiliki, b) motivasi ekstrinsik, yaitu motivasi yang datang karena adanya rangsangan atau pengaruh dari luar, motivasi ini bisa berasal dari keinginan untuk mendapatkan penghargaan, adanya kompetisi dan adanya masukan dan saran dari orang lain.

Motivasi selalu berkaitan dengan suatu tujuan. Seperti jika seseorang menginginkan menang dalam suatu lomba, maka ia akan selalu berlatih dengan giat agar kemenangan dalam perlombaan yang akan diikutinya. Dengan demikian motivasi itu mempengaruhi adanya kegiatan. Sehubungan dengan itu, ada tiga fungsi motivasi: 1) Mendorong manusia untuk berbuat; 2) menentukan arah perbuatan; dan 3) menyeleksi perbuatan. Selain daripada itu, motivasi juga dapat mendorong untuk pencapaian prestasi. Adanya motivasi yang baik dalam belajar akan menunjukkan hasil yang baik.

Ada beberapa cara untuk menumbuhkan motivasi dalam kegiatan belajar siswa di sekolah diantaranya dengan memberi nilai-nilai, hadiah, pujian, film pendidikan, mengadakan kompetisi, dan kerja kelompok. Menumbuhkan kesadaran kepada siswa agar merasakan pentingnya tugas dan menerimanya sebagai tantangan sehingga bekerja keras dengan mempertaruhkan harga diri adalah sebagai bentuk motivasi yang cukup penting (Arief S. Sadiman 2003: 91).

Berdasarkan pengertian motivasi diatas, dapat ditarik kesimpulan bahwa motivasi merupakan suatu usaha atau dorongan yang kuat dari dalam maupun dorongan dari luar diri seseorang untuk berbuat sesuatu dalam memenuhi keinginan, kebutuhan dan mencapai tujuan. 


\section{Motivasi belajar}

Pada dasarnya motivasi dapat membantu dalam memahami dan menjelaskan perilaku individu, termasuk individu yang sedang belajar. Peranan motivasi dalam belajar antara lain dalam menentukan hal-hal yang dapat menjadikan penguat belajar, yaitu dengan guru mengaitkan isi pelajaran dengan perangkat apapun yang berada paling dekat dengan siswa, memperjelas tujuan belajar yang hendak dicapai, menentukan kendali terhadap rangsangan belajar, dan menentukan ketekunan belajar.

Menurut W.S. Winkel (2004: 169) motivasi Belajar adalah keseluruhan daya penggerak psikis didalam diri siswa yang menimbulkan kegiatan belajar, menjamin kelangsungan kegiatan belajar dan memberikan arah kepada kegiatan belajar itu demi mencapai suatu tujuan. Sardiman (2007: 75) menyatakan bahwa motivasi belajar adalah keseluruhan daya penggerak di dalam diri siswa yang menimbulkan kegiatan-kegiatan belajar, yang menjamin kelangsungan dari kegiatan belajar dan yang memberikan arah pada kegiatan belajar, sehingga tujuan yang dikehendaki oleh subjek belajar itu dapat tercapai.

Motivasi belajar menurut Hamzah (2008:23) adalah dorongan internal dan eksternal pada siswa yang sedang belajar untuk mengadakan perubahan tingkah laku, pada umumnya dengan beberapa indikator atau unsur yang mendukung. Indikator motivasi belajar dapat diklasifikasikan sebagai berikut: 1) adanya hasrat dan keinginan berhasil; 2) adanya dorongan dan kebutuhan dalam belajar; 3) adanya harapan dan citacita masa depan; 4) adanya penghargaan dalam belajar; 5) adanya kegiatan yang menarik dalam belajar; 6) adanya lingkungan belajar yang kondusif, sehingga memnungkinkan seseorang dapat belajar dengan baik.

Motivasi belajar juga penting diketahui oleh seorang guru, pemahaman dan pengetahuan tentang motivasi belajar akan mendorong timbulnya tingkah laku dan mempengaruhi serta mengubah tingkah laku seseorang. Jadi, menurut Oemar Hamalik (2001: 161) ada tiga fungsi motivasi: 1) Mendorong timbulnya kelakuan dan perbuatan (belajar); 2) menentukan arah perbuatan; dan 3) sebagai penggerak, yaitu besarkecilnya motivasi akan menentukan cepat atau lambatnya suatu pekerjaan. Selain daripada itu, motivasi juga dapat mendorong untuk pencapaian prestasi. Adanya motivasi yang baik dalam belajar akan menunjukkan hasil yang baik. 
Menurut Slameto (1995) seringkali siswa yang tergolong cerdas tampak bodoh karena tidak memiliki motivasi untuk mencapai prestasi sebaik mungkin. Hal ini menunjukkan seorang anak didik yang cerdas, apabila memiliki motivasi belajar yang rendah maka dia tidak akan mencapai prestasi akademik yang baik. Sebaliknya, seorang anak didik yang kurang cerdas, tetapi memiliki motivasi yang tinggi untuk belajar, maka dia akan mencapai prestasi akademik yang baik.

Berdasarkan uraian di atas, maka motivasi belajar merupakan keseluruhan daya penggerak atau dorongan yang berasal dari dalam maupun dari luar diri seseorang yang sedang belajar untuk mengadakan perubahan tingkah laku sehingga menjamin keberlangsungan kegiatan belajar dan memberikan arah kepada belajar serta tujuan belajar dapat tercapai.

\section{Bahasa Arab Madrasah Tsanawiyah}

Menurut Yatim, dkk (2000) kata madrasah dalam bahasa Arab adalah bentuk kata keterangan tempat (zharaf makan) dari akar kata "darasa". Secara harfiah madrasah diartikan sebagai tempat belajar para pelajar, atau tempat untuk memberikan pelajaran. Dari akar kata darasa juga bisa diturunkan kata madras yang mempunyai arti buku yang dipelajari atau tempat belajar; kata al-midras juga diartikan sebagai rumah untuk mempelajari kitab Taurat.

Dalam proses belajar mengajar, madrasah tidaklah berbeda dengan sekolah secara umum. Orang awam di Indonesia memahami madrasah adalah sebagai sekolah agama yakni tempat anak didik belajar tentang seluk beluk agama dan keagamaan (Islam). Dalam praktiknya ada madrasah yang tidak hanya mengajarkan ilmu-ilmu agama tetapi juga mengajarkan ilmu-ilmu umum sebagaimana yang diajarkan disekolahsekolah umum, tetapi ada juga madrasah yang mengkhususkan diri pada pelajaran agama saja. (Zidni: 2004).

Proses pembelajaran pada satuan pendidikan baik madarasah maupun sekolah diselenggarakan secara interaktif, inspiratif, menyenangkan, menantang, memotivasi siswa untuk berpartisipasi aktif, serta memberikan ruang yang cukup bagi prakarsa, kreativitas, dan kemandirian sesuai dengan bakat, minat, dan perkembangan fisik serta psikologis siswa.

Mata Pelajaran bahasa Arab merupakan salah satu mata pelajaran yang ada pada Madrasah, dan mata pelajaran ini diarahkan untuk mendorong, membimbing, 
mengembangkan dan membina kemampuan serta menumbuhkan sikap positif terhadap bahasa Arab baik kemampuan secara reseptif maupun produktif. Kemampuan berbahasa Arab serta sikap positif terhadap bahasa Arab tersebut sangat penting dalam membantu memahami sumber ajaran Islam yaitu al-Qur'an dan Hadis, serta kitab-kitab berbahasa Arab yang berkenaan dengan Islam bagi peserta didik. Mata Pelajaran bahasa arab di Madrasah khususnya Madrasah Tsanawiyah dipersiapkan untuk pencapaian kompetensi dasar berbahasa, yang mencakup empat keterampilan berbahasa, yaitu menyimak (Istima'), berbicara (kalam), membaca (Qira'ah), dan menulis (kitabah).

Mata pelajaran Bahasa Arab memiliki tujuan : 1) mengembangkan kemampuan komunikasi dalam bahasa arab, baik lisan maupun tulis, yang mencakup empat kecakapan berbahasa, yakni menyimak (istima'), berbicara (kalam), membaca (qira'ah), dan menulis (kitabah); 2) menumbuhkan kesadaran tentang pentingnya bahasa Arab sebagai salah satu bahasa asing untuk menjadi alat utama belajar, khususnya dalam mengkaji suber-sumber ajaran Islam; 3) Mengembangkan pemahaman tentang saling berkaitan antara bahasa dan budaya serta memperluas cakrawala budaya. Dengan demikian, peserta didik diharapkan memiliki wawasan lintas budaya dan melibatkan diri dalam keragaman budaya.

Ruang lingkup pelajaran Bahasa arab di Madrasah Tsanawiyah meliputi tematema yang berupa wacana lisan dan tulisan berbentuk paparan atau dialog sederhana tentang identitas diri, kehidupan madrasah, kehidupan keluarga, rumah, hobi, profesi, kegiatan keagamaan, dan lingkungan. Pokok bahasan dalam pelajaran bahasa Arab di Madrasah tsanawiyah terintegrasi empat unsur kemahiran, yaitu yaitu menyimak (Istima'), berbicara (kalam), membaca (Qira'ah), dan menulis (kitabah). Keempat kemahiran tersebut dirangkaikan dala satu tema sehingga diharapkan mampu memberikan pengalaman yang bemakna pada siswa. Gambaran umum pokok bahasan materi pelajaran bahasa Arab; 1) mufrodat atau kosakata, merupakan kunci pertama untuk memahami teks sehingga siswa dilatih untuk menghafalkan mufrodat; 2) khiwar atau tanya jawab, 3) tarkib, 4) qira'ah; dan 5) kitabah.

\section{Hasil Penelitian}

Hasil analisis terhadap hasil rata-rata angket dari total jumlah siswa menunjukkan valid, reliable dan terdistribusi normal. Berikut perhitungan deskripsi nilai dari penggunaan media pembelajaran di kelas: 
Table 1. Hasil Nilai dari Angket Penggunaan Media Pembelajaran

\begin{tabular}{ccccc|c|c|c}
\hline & \multicolumn{2}{c}{ N } & & \multicolumn{1}{c|}{ Std. } & Min & Max & Sum \\
\cline { 2 - 5 } & Valid & Missing & & Deviasi & & & \\
\hline X & 94 & 0 & 25,82 & 4,56 & 18 & 37 & 2427 \\
\hline
\end{tabular}

Hasil Deskriptif data penggunaan media pembelajaran dalam penelitian ini diterangkan bahwa terdapat jumlah 94 siswa yang mengisi angket dengan rata-rata (mean) sebesar 25,82; simpangan baku (standar deviasi)=4,56; skor minimum dari data penggunaan media pembelajaran yang peling rendah = 18 dan skor maksimum dari data penggunaan media pembelajaran $=37$. Sedangkan jumlah skor ke seluruhan sebesar 2427.

Hasil Deskriptif data motivasi belajar siswa dalam penelitian ini diterangkan bahwa terdapat jumlah 94 siswa yang mengisi angket dengan rata-rata (mean) sebesar 64,52; simpangan baku (standar deviasi)= 5,78; skor minimum dari data motivasi belajar siswa motivasi belajar siswa yang paling rendah $=51$ dan skor maksimum dari data motivasi belajar siswa $=78$. Sedangkan jumlah skor ke seluruhan sebesar 6065 . Rincian hasil dari perhitungan diskriptif nilai data motivasi belajar bahasa Arab dalam tabel adalah sebagai berikut:

Table 2. Hasil Nilai Data Motivasi Belajar

\begin{tabular}{ccccccccc}
\hline & \multicolumn{2}{c}{ N } & & \multicolumn{2}{c}{ Std. } & Min & Max & Sum \\
\cline { 2 - 5 } & Valid & Missing & Mean & Deviasi & & & \\
\hline X & 94 & 0 & 64,52 & 5,78 & 51 & 78 & 6065 \\
\hline
\end{tabular}

Berdasarkan uji hipotesis diperoleh, besarnya koefisien korelasi (r) yaitu sebesar 0,4723 lebih besar dari 0,207 dengan taraf signifikan 5\%. Dengan demikian dapat disimpulkan bahwa $\mathrm{H}_{\mathrm{a}}$ diterima yaitu terdapat "pengaruh penggunaan media pembelajaran terhadap motivasi belajar bahasa Arab siswa". Hasil penelitian ini menginformasikan terdapat pengaruh yang signifikan antara media pembelajaran terhadap motivasi belajar siswa, khusunya dalam belajar bahasa Arab. Hal ini berarti bahwa jika dalam pembelajaran geuru menggunakan secara maksimal media pembelajaran, maka motivasi dalam belajarpun akan tinggi. Sebaliknya jika dalam penggunaan media minim, maka motivasinyapun akan rendah. 


\section{Simpulan}

Hasil penelitian ini menginformasikan terdapat pengaruh yang signifikan antara media pembelajaran terhadap motivasi belajar siswa, khusunya dalam belajar bahasa Arab. Hal ini berarti bahwa jika dalam pembelajaran geuru menggunakan secara maksimal media pembelajaran, maka motivasi dalam belajarpun akan tinggi. Sebaliknya jika dalam penggunaan media minim, maka motivasinyapun akan rendah.

\section{Daftar Rujukan}

Arikunto, S. Manajemen Penelitian. Jakarta: Rineka Cipta, 1998. . Prosedur Penelitian Suatu Pendekatan Praktik. Jakarta: Rineka Cipta, 2006.

Arsyad, A. Bahasa arab dan Metode Pengajarannya. Yogyakarta: Pustaka Pelajar, 2004. Media Pembelajaran. Jakarta: Rajawali Pers, 2009.

Badudu. Kamus Umum Bahasa Indonesia. Jakarta: Pustaka Sinar Harapan, 2001.

Hamalik, O. Psikologi Belajar dan Mengajar. Bandung: Sinar Baru Algensindo, 2002.

Hamid, A. Pembelajaran Bahasa Arab; pendekatan metode, strategi, materi dan media. Malang: UIN-Malang Press, 2008.

Makruf, I. Strategi Pembelajaran Bahasa Arab Aktif. Semarang: Need's Press, 2009.

Munawwir, A. W. Kamus Al- Munawwir Indonesia-Arab Terlengkap. Surabaya: Pustaka Progressif, 2007.

Purwanto, M. N. Psikologi Pendidikan. Bandung: Remaja Rosdakarya, 2004.

Sadiman, A. S. Media Pendidikan pengertian, pengembangan dan pemanfaatannya. Jakarta: Rajagrafindo Persada, 2003.

Sardiman. Interaksi dan Motivasi Belajar Mengajar. Jakarta: PT. Raja Grafindo Persada, 2010.

Shaleh, A. \& Wahab, M. A. Psikologi Pendidikan Suatu pengantar dalam persepektif Islam. Jakarta: Kencana, 2004.

Sudjana, N. Media Pembelajaran. Bandung: Sinar Baru Algensindo, 2002.

Sugiyono. Statistika Untuk Penelitian. Bandung: Alfabeta, 2007.

Syah, M. Psikologi Pendidikan. Bandung: Remaja Rosdakarya, 2006.

Uno, H. B. Teori motivasi dan pengukurannya. Jakarta: Bumi Aksara, 2008. 
Wahab, M. A. Epistomologi dan Metodologi Pembelajaran Bahasa Arab. Jakarta: Lembaga Penelitian UIN Syarif Hidayatullah, 2008.

Yatim, B, dkk. Sejarah Perkembangan Madrasah. Jakarta : Departemen Agama RI, Direktorat Jendral Pembinaan Kelembagaan Agama Islam, 2000.

Zidni. Penalaran Moral Pada Siswa Sltp Umum Dan Madrasah Tsanawiyah. Humanitas : Indonesian Psychologycal Journal Vol.1 No. 2 Agustus 2004:25-32., , 2004. 